\title{
Evaluating the social, economic, and environmental drivers of urban brownfields redevelopment in Santa Cruz, Bolivia
}

\author{
H. E. Wright Wendel \& J. R. Mihelcic \\ Department of Civil and Environmental Engineering, \\ University of South Florida, USA
}

\begin{abstract}
Throughout the developed and the developing world, brownfield sites continue to be created, even while the inventory of these sites lag behind. In the city of Santa Cruz, Bolivia, abandoned brick factories have become illegal dumps that threaten human health, the environment, and ultimately the economic viability of the communities where they are located. This paper begins to examine the driving factors behind brownfields redevelopment in Bolivia. Perceived benefits of redevelopment projects are compared to gain a better understanding of the differences and similarities that may exist between developed and developing countries. A case study of a brownfield site in Santa Cruz is explored to highlight the connections between various types of risks and the desired social and economic values and ecological functions.
\end{abstract}

Keywords: brownfields redevelopment, developing world, sustainable waste management, Santa Cruz, Bolivia, sustainability, risk, greenspace, health.

\section{Introduction}

The term "brownfields" is often used in developed countries to indicate former industrial and commercial sites that are either contaminated, unused, and/or abandoned [1]. Alker et al. [2] defines a brownfield site as "any land or premises which has previously been used or developed and is not currently fully in use, although it may be partially occupied or utilized. It may also be vacant, derelict or contaminated. Therefore a brownfield site is not available for immediate use 
without intervention." Based on this definition, brownfields can be located within both developed and developing countries.

At the international level, several frameworks and programs exist that address development issues, such as ecological conservation and environmental risks. The United Nations' Agenda 21 and Millennium Development Goals are two examples that have international implications for brownfields redevelopment $[3,4]$. As an example, the following areas were highlighted as goals for shaping the Bolivian National Solid Waste Management Strategy, to avoid the creation of additional brownfield sites [5]:

- Chapter 21 of Agenda 21: a) Reduce waste production; b) Increase environmentally favorable waste reuse and recycling; c) Promote environmentally favorable waste disposal and treatment; and d) Expand waste service coverage.

- Goal 7 of the Millennium Development Goals: a) Integrate sustainable development principles into policies and programs to reverse losses of natural resources; b) Reduce biodiversity loss; c) Reduce, by half, the percentage of people lacking sustainable access to safe drinking water and basic sanitation by 2015; and d) Significantly improve, by 2020, the lives of at least 100 million slum dwellers.

\subsection{Estimated extent of brownfields in the United States}

Brownfield sites are often associated with negative perceptions, yet these sites often represent under-utilized potential within urban areas [6]. Some of these perceptions include visual blight, lower municipal revenues, environmental and health risks, safety hazards, crime, and illegal dumping [7]. Unfortunately, many communities do not even have formal inventories of their brownfield sites. This is often the case in communities with less intensive industrial pasts (i.e., less potential for brownfields), or due to fear that property values may be reduced if brownfield sites are publicly documented within the community [7]. In developed countries, even though brownfields may occupy only a small percentage of urban land, these sites can represent a significant problem because of their concentrated locations. For example, in the U.S., 2-3 percent of the total land area is built on (primarily urban) [8]; however, the estimated 450,000 brownfield sites may occupy 6-15 percent of that urban land $[1,7,9]$.

\subsection{Extent of brownfields largely unknown in Bolivia}

Although the term "brownfield" is often used in developed countries to describe vacant or contaminated industrial or commercial sites, it can also be applied to areas in developing countries that have been contaminated by a variety of domestic or industrial uses (e.g., legal and illegal waste disposal, untreated wastewater, commercial processes). In developing countries, brownfield sites are not only unaccounted for, but they are often still being created as communities struggle to develop and deal with increasing quantities of less organic wastes. 
Due to the changing composition in the waste streams of many developing countries - from primarily organic to more commonly non-biodegradable many brownfield sites are created due to improper solid waste disposal $[5,10]$. In the city of Santa Cruz, Bolivia, at least 53 sites (0.25-5 hectares, 1-4 meters deep) exist that are abandoned brick-making enterprises (ex-tejerias); 12 of which have been converted into illegal dumps (curichis) [10]. Some of these extejerias are left to natural succession; however, the majority are either used to illegally dispose of all types of wastes or are legally filled in with construction debris and other rubble to create areas for housing.

\subsection{Objectives}

The health benefits derived from exposure to green spaces, such as enhanced physical activity and reduced blood pressure and stress levels, have been documented by previous studies [11,12]. Mitchell and Popham [11] found that populations exposed to areas with more green space had lower levels of incomerelated health inequalities; while those populations lacking green space exposure were less protected from health inequalities related to income deprivation.

Therefore, in terms of reducing health and other social inequalities, it is appears to be beneficial for communities going through rapid urbanization to either protect their natural environments, or to restore green spaces via brownfields redevelopment [11]. This paper will examine a variety of driving factors behind brownfield redevelopment projects in the developing and developed world. Specifically this paper will:

- Assess the environmental, social, and economic benefits that impact brownfields redevelopment projects; and

- Determine the connections between environmental, social, and economic risks and the desired societal values and ecological functions of a case study brownfield site located in the developing world.

\section{Case study: brownfields in Santa Cruz, Bolivia}

\subsection{Socio-economic condition of Bolivia}

According to the World Resources Institute [13], 1.3 million Bolivians live on less than one dollar per day, with 5.1 million living below the basic needs poverty line. In 2001, 61 percent of the Bolivian urban population was living in slum conditions, whereas the average in South America was only 36 percent. Additionally, Bolivia has a large gap in economic equality - the wealthiest 20 percent of the population account for almost half of the total spending, yet the poorest 20 percent account for only four percent. As illustrated in table 1, despite the socio-economic problems of Bolivia, it is rich in natural capital. More than 11 percent of the total land area is protected in Bolivia, which is well above the 5.9 percent average for South America. 


\subsection{Brownfields formation in Santa Cruz, Bolivia}

In the last several decades, the population of Santa Cruz has grown rapidly to over 2 million inhabitants, making it the largest city in Bolivia. While the national growth rate for Bolivia was 2.7 percent between 1992-2001 (3.6 percent in urban areas and 1.4 percent in rural areas), the department of Santa Cruz grew at a rate of 4.3 percent (4.9 percent in urban areas and 2.6 percent in rural areas) during the same time period [14]. With this population growth, throughout the city of Santa Cruz, green space has been lost due to urban development. However, much of the remaining green space has been degraded by improper municipal waste management practices [10]. The loss of green space and poor waste management have resulted in: 1) increased groundwater pollution and urban stormwater drainage problems; 2) reduced air quality; and 3) loss of natural resources $[5,10,15]$.

Table 1: $\quad$ Socio-economic indicators for the United States and Bolivia [13].

\begin{tabular}{|l|l|l|}
\hline Indicators & United States & Bolivia \\
\hline Population (2006) & $300,038,000$ & $9,138,000$ \\
\hline Population annual growth rate & 1.10 & 2.74 \\
\hline Life expectancy (years) & 77.3 & 63.9 \\
\hline Number living on $>\$ 1 /$ day & - & $14.4 \%$ \\
\hline National Poverty Rate & - & $62.7 \%$ \\
\hline Human Development Index (1=most developed) & 0.94 & 0.68 \\
\hline GDP per capita (2002) & $\$ 35,746$ & $\$ 2,459$ \\
\hline Health care expenditures per capita, total (2001) & $\$ 4,887$ & $\$ 125$ \\
\hline Male Annual income & $\$ 43,797$ & $\$ 3,463$ \\
\hline Female Annual income & $\$ 27,338$ & $\$ 1,559$ \\
\hline Total land protected & $8.4 \%$ & $11.1 \%$ \\
\hline Number of wetlands of international importance & 21 & 8 \\
\hline Number of biosphere reserves & 47 & 3 \\
\hline
\end{tabular}

Throughout Santa Cruz (figure 1), many brownfield sites have been created as a result of unsustainable waste management. These sites are an indirect result of brick-making enterprises, which create depressions in the landscape as they extract clay soil. Once abandoned, these depressions develop into wetland-type habitats. However, rapidly expanding city limits have placed these sites within or near communities. Due to a lack of waste management and education, residents use these sites to illegally dispose of all types of wastes, including hazardous and biological wastes [10]. After decades of degradation, these curichis have lost much of their natural water-storage capacity as well as biodiversity [15].

Much of the waste discarded in these curichis (e.g., tires, plastics, metals, electronics) is processed via open burning, which is detrimental to both human health and the environment. Residents have reported health problems they associate with open burning events; however, many of the low-income communities lack the resources and knowledge to effectively change these longstanding social practices or engage the assistance of the municipal government.

Air pollution, water contamination, direct contact, and disease transmission are several of the important exposure routes identified for improperly disposed 


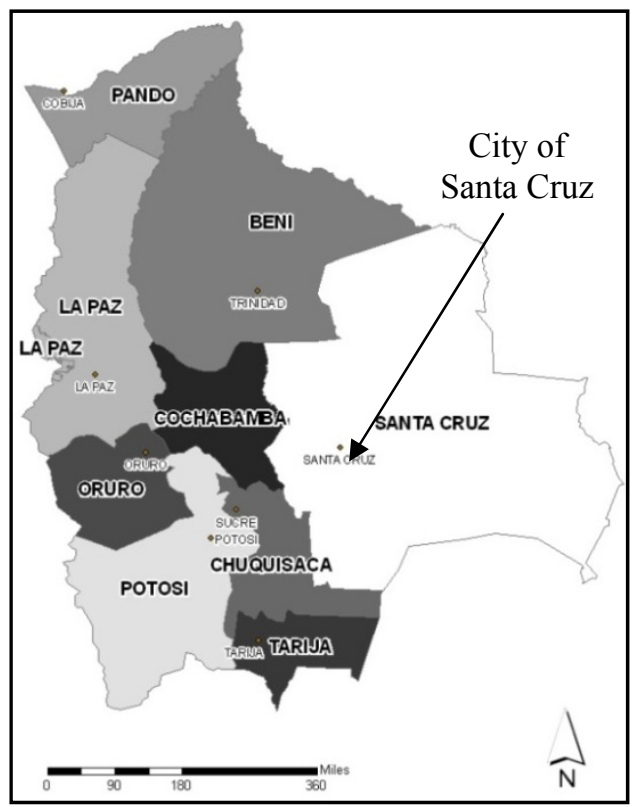

Figure 1: $\quad$ Map of land-locked Bolivia, including the department of Santa Cruz and the city of Santa Cruz.

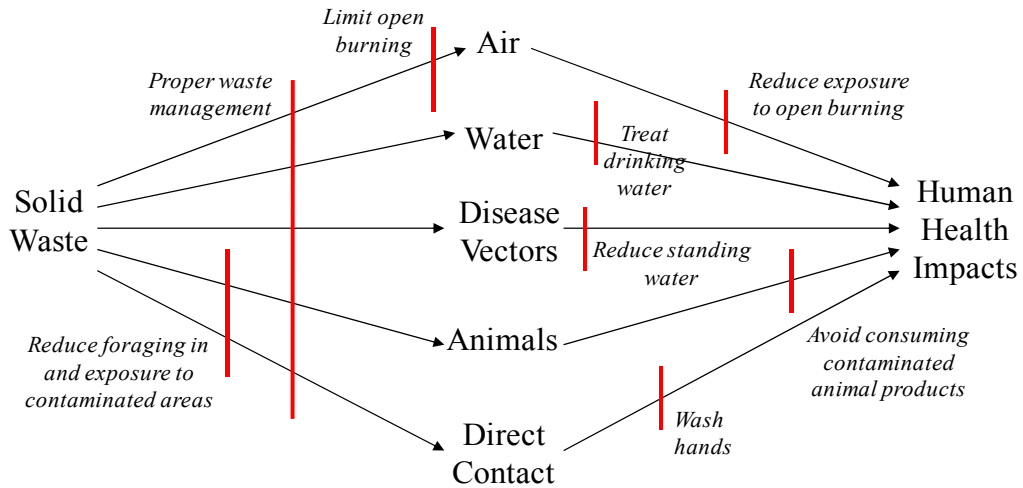

Figure 2: $\quad$ Modified "F-Diagram" developed for this study for solid waste that includes five routes of exposure: air, water, disease vectors, animals, and direct contact. Barriers to transmission, indicated by italics, include engineering and policy solutions and social behavior changes - all requiring a certain level of formal or informal education.

municipal waste in Santa Cruz curichis (figure 2). These exposure routes have the greatest socio-economic impacts for residents, particularly children [10]. 


\section{Results}

The benefits of brownfields redevelopment in developed countries are well documented [7,12,16-18]; however, brownfields and other contaminated sites are just now starting to be considered in some developing countries $[5,10,19]$. Therefore, it is important to identify the potential benefits of brownfields redevelopment in order to restore the desired values and functions of these sites. Benefits of brownfields redevelopment were identified for a developed country (U.S.) and a developing country (Bolivia) to examine differences and similarities that may exist. Key environmental, economic, and social benefits were selected based on available literature and the primary author's experience with brownfield sites in Bolivia (table 2).

Table 2: $\quad$ Potential benefits of brownfields redevelopment that are perceived in the U.S. and Bolivia - assuming mixed projects of residential/retail and various types of green space $[11,12,16,17,20]$.

\begin{tabular}{|c|c|c|}
\hline Type of Benefit & Developed (U.S.) & Developing (Bolivia) \\
\hline \multicolumn{3}{|c|}{ Environmental Benefits } \\
\hline $\begin{array}{l}\text { Reduce health } \\
\text { risks }\end{array}$ & $\begin{array}{l}\text { Reduce chronic health risks such as } \\
\text { cancer, nervous system damage, } \\
\text { heavy metal poisoning, etc; }\end{array}$ & $\begin{array}{l}\text { Reduce acute health risks (i.e., } \\
\text { malaria, diarrhea, respiratory } \\
\text { ailments) and chronic risks }\end{array}$ \\
\hline $\begin{array}{l}\text { Creation of green } \\
\text { space }\end{array}$ & $\begin{array}{l}\text { Contribute to maintaining } \\
\text { biodiversity, moderating the heat } \\
\text { island effect, reducing pollution, and } \\
\text { demonstrating sustainable urban } \\
\text { environmental management }\end{array}$ & $\begin{array}{l}\text { Provide sustainable stormwater } \\
\text { drainage, pollution reduction, } \\
\text { urban wildlife habitat, and } \\
\text { community gathering sites (i.e., } \\
\text { soccer field, parks) }\end{array}$ \\
\hline $\begin{array}{l}\text { Environmental } \\
\text { justice }\end{array}$ & $\begin{array}{l}\text { Increase access by lower-income } \\
\text { residents to environmental } \\
\text { recreational opportunities }\end{array}$ & $\begin{array}{l}\text { Reduce exposure by lower- } \\
\text { income residents to illegal dumps } \\
\text { and associated health risks }\end{array}$ \\
\hline \multicolumn{3}{|c|}{ Economic Benefits } \\
\hline Job creation & $\begin{array}{l}\text { Increase local and regional jobs in } \\
\text { retail, housing services, and/or park } \\
\text { maintenance }\end{array}$ & $\begin{array}{l}\text { Increase opportunities for } \\
\text { individual family businesses or } \\
\text { green space maintenance }\end{array}$ \\
\hline \begin{tabular}{|l|} 
Spill-over \\
economic effects
\end{tabular} & $\begin{array}{l}\text { Improve overall neighborhood } \\
\text { quality, attract investment, increase } \\
\text { property values, and stimulate local } \\
\text { economies }\end{array}$ & $\begin{array}{l}\text { Reduce crime, improve } \\
\text { community health, and prevent } \\
\text { flood damage }\end{array}$ \\
\hline $\begin{array}{l}\text { Prevent housing } \\
\text { abandonment }\end{array}$ & $\begin{array}{l}\text { Increase desirability to live in urban } \\
\text { area and reduce urban sprawl } \\
\text { pressures }\end{array}$ & $\begin{array}{l}\text { Reduce crime and improve } \\
\text { aesthetics }\end{array}$ \\
\hline \multicolumn{3}{|c|}{ Social Benefits } \\
\hline $\begin{array}{l}\text { Restore } \\
\text { neighborhood } \\
\text { empowerment }\end{array}$ & $\begin{array}{l}\text { Improve residents' overall well- } \\
\text { being and renew sense of pride in } \\
\text { community }\end{array}$ & $\begin{array}{l}\text { Improve overall residents' well- } \\
\text { being and renew sense of hope in } \\
\text { community }\end{array}$ \\
\hline $\begin{array}{l}\text { Use of existing } \\
\text { infrastructure }\end{array}$ & $\begin{array}{l}\text { Reduce pressure on undeveloped } \\
\text { greenfields }\end{array}$ & $\begin{array}{l}\text { Reduce development costs and } \\
\text { protect green spaces }\end{array}$ \\
\hline \begin{tabular}{|l|} 
Improve city \\
services
\end{tabular} & $\begin{array}{l}\text { Increase tax revenues and revitalize } \\
\text { urban landscape }\end{array}$ & $\begin{array}{l}\text { Increase urban drainage and } \\
\text { improve recreation areas }\end{array}$ \\
\hline
\end{tabular}


For both the U.S. and Bolivia, incorporating green space into brownfields redevelopment would help provide safe access to urban environmental services (i.e., recreation opportunities, urban wildlife habitat, pollution reduction, etc), which would restore economic and social values and enhance urban environmental functions. Additionally, both countries would benefit from reduced health risks (both chronic and acute for Bolivians), greater environmental justice - particularly for lower-income groups, and greater overall well-being for residents. The differences between the two countries were most apparent for the economic benefits of redevelopment. Communities in the U.S. would benefit from increased jobs, tax revenues, and property values, as well as reduced urban sprawl; whereas communities in Bolivia would benefit from reductions in flood damage, crime, and health risks (and their associated costs).

Figures 3 and 4 illustrate the connections between various types of risks and the desired social and economic values and ecological functions for curichi brownfield sites in Santa Cruz, Bolivia. Figure 3 focuses on engineering and policy solutions that would reduce existing human health risks as well as restore ecological functions and societal values to the curichis. Figure 4 demonstrates important social behavior changes that would reduce economic, human health, and environmental risks, achieve societal and economic benefits, and restore societal values and ecological functions to the curichis in Santa Cruz. In order to achieve the desired brownfield functions and values, both engineering/policy solutions and social behavior changes need to be jointly implemented. As shown with the Bolivian National Solid Waste Management Strategy [5], policies and practices are being discussed at the national level to improve solid waste management. Incorporating environmental education into the Bolivian school system has been put forth as a primary method for achieving these desired behavior changes in the long term [5]. Currently, few schools in Santa Cruz have any sort of environmental education program; however, this is beginning to change. Several small-scale environmental education programs have been initiated despite funding issues, which has reduced the extent to which these programs can be implemented, particularly for public schools [21].

The larger issue with the redevelopment of brownfields in Santa Cruz, as with many other areas in the world, is creating an awareness of the inter-related problems of environmental degradation, human health impacts, and economic viability. Additionally, these long-term problems require collaborative partnerships between diverse stakeholders that includes learning and trustbuilding among all participants.

\section{Acknowledgements}

Research was supported by the Sustainable Futures IGERT project sponsored by the U.S. National Science Foundation (under Grant No. DGE 0333401) and a NSF Graduate Research Fellowship awarded to Heather E. Wright Wendel. 


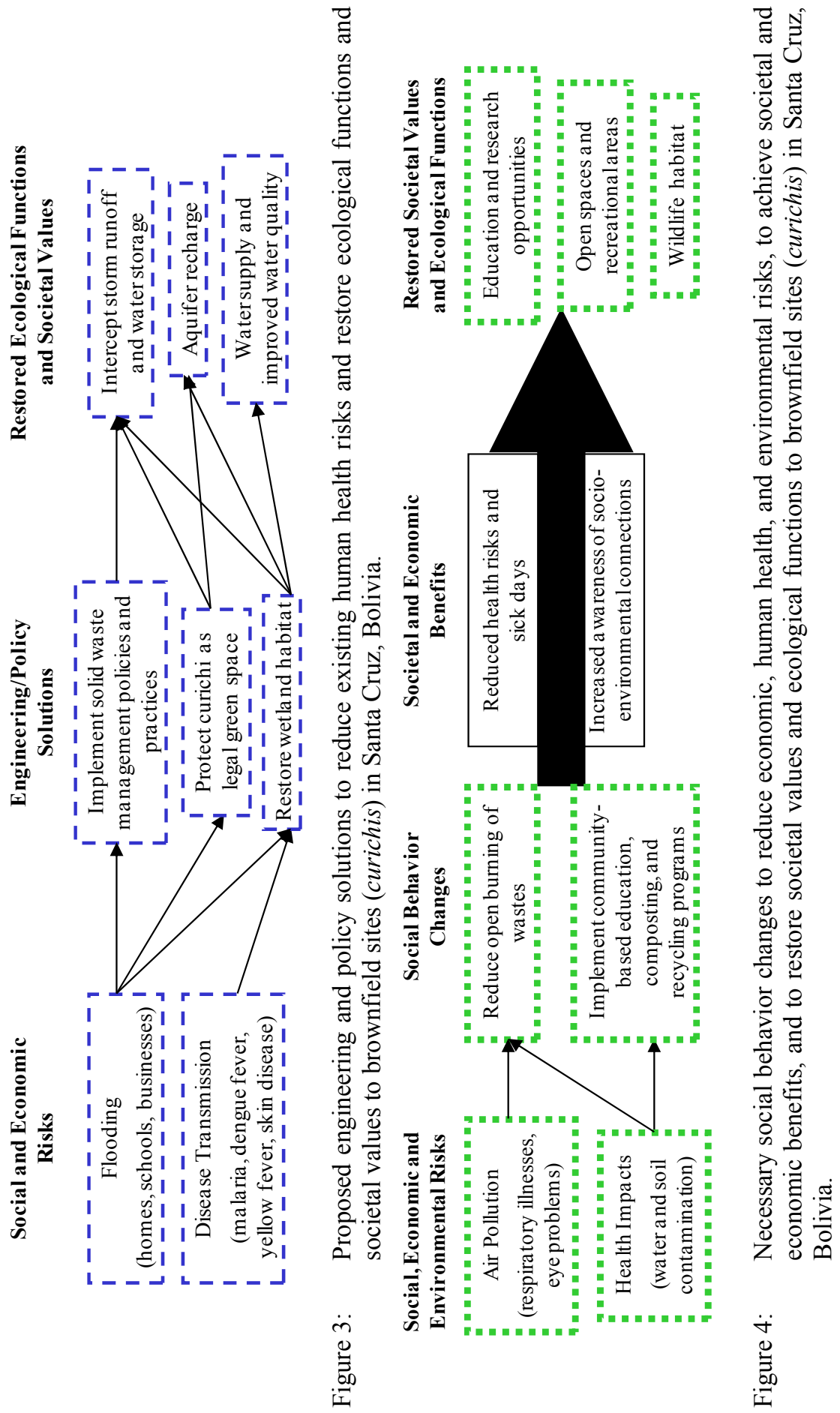

WIT Transactions on Ecology and the Environment, Vol 122, (c) 2009 WIT Press www.witpress.com, ISSN 1743-3541 (on-line) 


\section{References}

[1] US Environmental Protection Agency. Brownfields and Land Revitalization, http://www.epa.gov/brownfields/

[2] Alker, S., Joy, V., Roberts, P. \& Smith, N., The definition of brownfield. Journal of Environmental Planning and Management, 43(1), pp. 49-69, 2000.

[3] UN Department of Economic and Social Affairs. Agenda 21, http://www.un.org/esa/sustdev/documents/agenda21/index.htm

[4] United Nations Development Programme. Millennium Development Goals, http://www.undp.org/mdg/basics.shtml

[5] Ministerio de Servicios y Obras Publicas, Estrategia Nacional para la Gestión Integral de Residuos Sólidos. Ministerio de Servicios y Obras Públicas: La Paz, Bolivia, 2005.

[6] DePass, M., Brownfields as a tool for rejuvenation of land and community. Local Environment, 11(5), pp. 601-606, 2006.

[7] DeSousa, C.A., Urban brownfields redevelopment in Canada: the role of local government. The Canadian Geographer, 50(3), pp. 392-407, 2006.

[8] Mihelcic, J.R. \& Zimmerman, J.B., Environmental Engineering: Fundamentals, Sustainability, Design, John Wiley \& Sons: New York, 2009.

[9] Pagano, M.A. \& Bowman, A.O.M., Vacant Land in Cities: An Urban Resource. The Brookings Institution: 2000.

[10] Gobierno Municipal de Santa Cruz de la Sierra, Estudio, Identificacion, Cuantificacion y Evaluacion Tecnica de Pasivos Ambientales, Botaderos Clandestinos en el Municipio de Santa Cruz. Oficialia Mayor de Desarrollo Economico y Medio Ambiente, Departmento de Residuos Solidos y Sustancias Peligrosas: Santa Cruz, 2004.

[11] Mitchell, R. \& Popham, F., Effect of exposure to natural environment on health inequalities: an observational population study. The Lancet, 372(9650), pp. 1655-1660, 2008.

[12] DeSousa, C.A., Turning brownfields into green space in the City of Toronto. Landscape and Urban Planning, 62(pp. 181-198, 2003.

[13] World Resources Institute, World Resources 2005: The Wealth of the Poor -- Managing Ecosystems to Fight Poverty. Washington, DC, 2005.

[14] Instituto Nacional de Estadística, Tasa Anual de Crecimiento Intercensal de la Poblacíon por Área. 2008.

[15] Museo de Historia Natural Noel Kempff Mercado, Diagnostico Biofisico y Georeferencial del Area de Proteción Ecologica del Rio Piraí. Santa Cruz de la Sierra, Bolivia, 2007.

[16] Deason, J.P., Sherk, G.W. \& Carroll, G.A., Public Policies and Private Decision Affecting the Redevelopment of Brownfields: An Analysis of Critical Factors, Relative Weights and Areal Differentials. The George Washington University: Washington, DC, 2001. 
[17] Dorsey, J.W., Brownfields and Greenfields: The Intersection of Sustainable Development and Environmental Stewardship. Environmental Practice, 5(1), pp. 69-76, 2003.

[18] Paull, E., Energy Benefits of Urban In-fill and Brownfields Redevelopment. Northeast-Midwest Institute: 2007.

[19] Bezama, A., Agüero, R., Márquez, F., Barrera, S., Salazar, N. \& Lorber, K.E., Land register of contaminated sites in an industrial chilean region: Identification and evaluation of suspected sites. Waste Management, 28 (pp. 588-596, 2008.

[20] Swanwick, C., Dunnet, N. \& Woolley, H., Nature, Role and Value of Green Space in Towns and Cities: An Overview. Built Environment, 29(2), pp. 94-106, 2003.

[21] Colque, F. Personal Communication, August 19, 2008, Environmental Engineering Professor, Santa Cruz, Bolivia. 